\title{
Diffusive Fluxes of $\mathrm{CH}_{4}$ and $\mathrm{CO}_{2}$ at the Sediment-Overlying Water Interface in Reservoir Ecosystems
}

\author{
Renata Gruca-Rokosz' \\ 1 Department of Environmental and Chemistry Engineering, Faculty of Civil and Environmental Engineering \\ and Architecture, Rzeszów University of Technology, Rzeszów, Poland, e-mail: renatagr@prz.edu.pl
}

\begin{abstract}
The work detailed here concerned the $\mathrm{CH}_{4}$ and $\mathrm{CO}_{2}$ fluxes at the sediment-overlying water interface in Maziarnia and Nielisz Reservoirs, SE Poland. The research in question was conducted in the period of 2009-2011, the samples of sediment and overlying water were collected at two stations located in the upper and lower parts of each reservoir. The concentrations of $\mathrm{CO}_{2}$ and $\mathrm{CH}_{4}$ in pore water and overlying water were measured with the headspace method, using a Pye Unicam gas chromatograph (PU-4410/19) equipped with a methane analyzer allowing low $\mathrm{CO}_{2}$ concentrations to be detected. Diffusive fluxes of the analyzed gases at the sediment-overlying water interface were calculated on the basis of Fick's first law, and were found to range from -0.01 to $3.48 \mathrm{mmol} \times \mathrm{m}^{-2} \times \mathrm{d}^{-1}$ for $\mathrm{CH}_{4}$ and from -1.27 to $47.02 \mathrm{mmol} \times \mathrm{m}^{-2} \times \mathrm{d}^{-1}$ for $\mathrm{CO}_{2}$. Comparable fluxes elsewhere typify the reservoirs experiencing far-reaching eutrophication. No dependent relationships were found between the values calculated for fluxes and either season of the year or sediment characteristics.
\end{abstract}

Keywords: methane, carbon dioxide, greenhouse gasses, reservoir, sediments

\section{INTRODUCTION}

Reservoirs form the subject of many studies considering a host of different aspects. However, where threats are concerned, one of the most fundamental and probably most commonly described one relates to an intensive supply with biogenic compounds (Bartoszek and Koszelnik 2016; Bartoszek and Tomaszek 2011, 2016), and consequent increases in primary production. When either allochthonous or autochthonous organic matter dies, it accumulates as deposits in bottom sediments, where it becomes subject to decomposition. If this process takes place under anaerobic conditions, the ensuing fermentation generates gaseous end products in the form of both methane $\left(\mathrm{CH}_{4}\right)$ and carbon dioxide $\left(\mathrm{CO}_{2}\right)$, i.e. two key pollutants acting as greenhouse gases (IPPC 2007).

While $\mathrm{CO}_{2}$ and $\mathrm{CH}_{4}$ from sediments can enter the water column - from where they can reach the atmosphere - by diffusion or ebullition, the amounts of the gases actually doing so are not equivalent to those generate by sediments, given that both gases may be consumed in the water column, i.e. as a result of photosynthesis or oxidation. For this reason, a complete picture of the carbon cycle in reservoirs is only obtained where $\mathrm{CH}_{4}$ and $\mathrm{CO}_{2}$ fluxes are studied at both the sediment-overlying water and the water-air interfaces.

Findings from the studies of the above-mentioned phenomena are thus seen to constitute an important link in determining the overall carbon balances for reservoirs, as well as providing insights into the functioning of these aquatic ecosystems. In the case of this paper, the objective was to study the $\mathrm{CH}_{4}$ and $\mathrm{CO}_{2}$ fluxes at the sediment-overlying water interface in two reservoirs in SE Poland.

\section{MATERIALS AND METHODS}

\section{Study area}

The reservoirs in two different voivodeships of south-eastern Poland were selected for study. Maziarnia Reservoir is found in the Podkarpackie 
voivodeship, while Nielisz Reservoir is located in the Lubelskie voivodeship. The characteristic parameters of these Reservoirs were shown in Figure 1. At each water reservoir, the research was conducted at two characteristic stations located in the shallows. However, while the stations $\mathrm{M} 1$ and N1 were located close to the respective dams, the stations M2 and N2 were situated in the upper part of each Reservoir.

\section{Sediment and water sampling and preparation}

The work was carried out in 2009 (MaziarniaOctober), 2010 (Maziarnia - June, September; Nielisz - June, July, September) and 2011 (Maziarnia and Nielisz - May, June, July, August, September). The samples of sediment and overlying water were collected 8 times in the case of each Reservoir, with sediment cores taken from the littoral using a gravity (KC Kajak of Denmark) sediment corer. Three such cores, together with overlying water, were immediately transported to the laboratory. In the top $(1 \mathrm{~cm})$ layers of the sediment from two cores porosity, $\mathrm{pH}$, organic matter (OM), total organic carbon (TOC) and total nitrogen $(\mathrm{TN})$ were all measured. In turn, the surface layer of the third core provided pore water, which was squeezed out directly into gas-tight vials, using a modified pore-water squeezer (Reeburgh 1967) for the analysis of $\mathrm{CO}_{2}$ and $\mathrm{CH}_{4}$ concen- trations. In order to ensure that the contact with the atmosphere was avoided, pore water obtained was collected directly in gastight glass vials. Overlying water was stored in the same way, with a polypropylene syringe connected to a hose used for collection, with samples in vials immediately being acidified using $6 \mathrm{~N} \mathrm{HCl}$ (final concentration $\sim 50 \mathrm{mmol} \times \mathrm{dm}^{-3}$ ), in order to ensure the quantitative conversion of all carbonate anions into $\mathrm{CO}_{2}$ (Miyajima et al. 1995).

\section{Analysis of pore-water and overlying water}

The concentrations of gas in the pore-water and overlying water were analyzed using a headspace equilibration technique. The gases were extracted from water into the afore-mentioned gastight glass vials, displacing a known volume of water using helium as they did so. Water was equilibrated in the vials with added helium, by 5 minutes of vigorous shaking. The gas samples were then taken from the headspace and analyzed for their concentrations of $\mathrm{CH}_{4}$ and $\mathrm{CO}_{2}$.

The concentrations of both $\mathrm{CH}_{4}$ and $\mathrm{CO}_{2}$ were measured using a Pye Unicam gas chromatograph with the analytical error of $\pm 5 \%$ (model PU-4410/19), as equipped with a flame ionization detector (FID) and a stainless steel column packed with a Haye Sep Q, 80/100 Mesh, $6 \mathrm{ft}$. in length and of $2 \mathrm{~mm}$ ID. The GC was also equipped with a methanizer to detect low levels

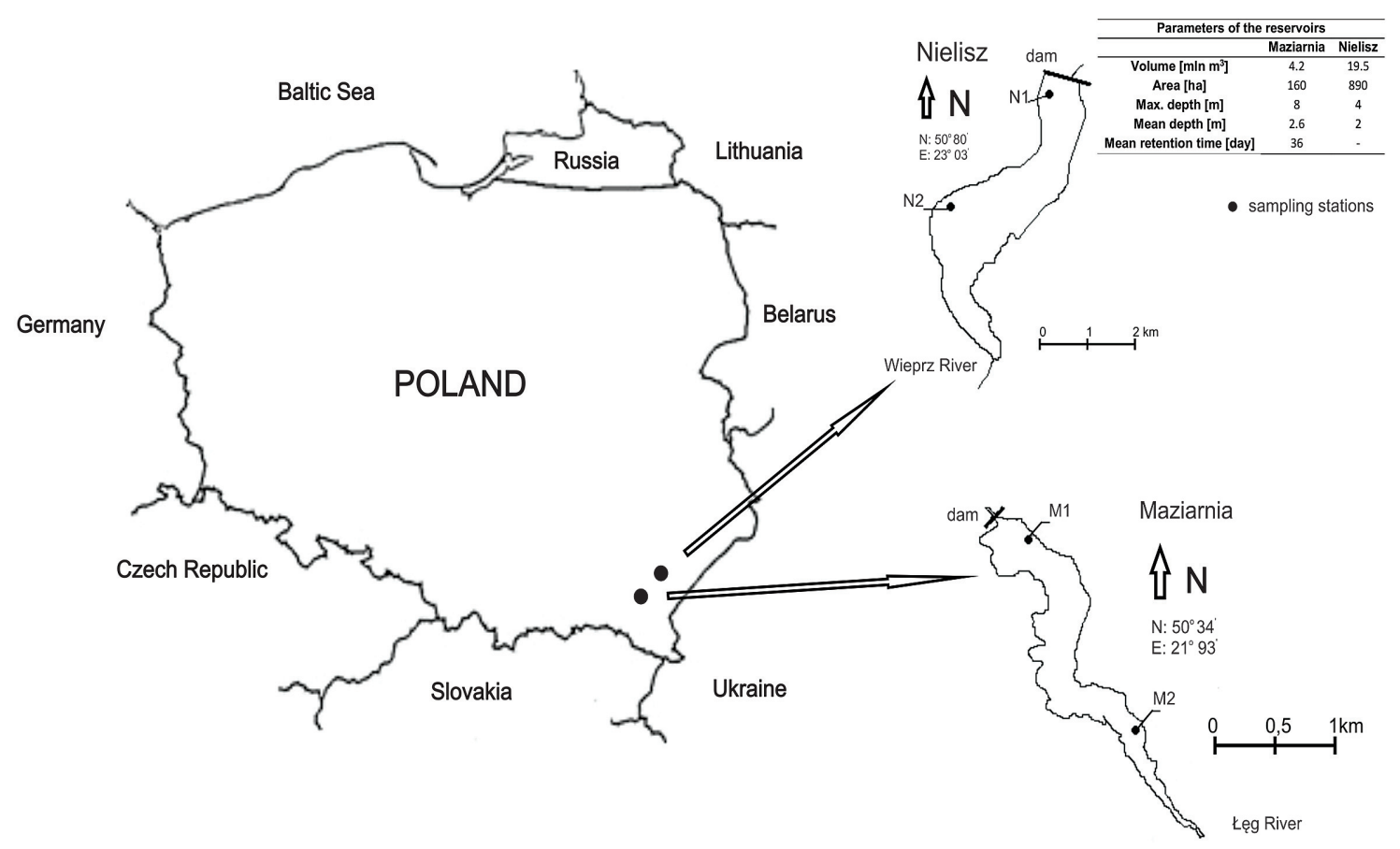

Fig. 1. Locations of the Reservoirs studied and the sampling stations 
of carbon dioxide. This is packed with a nickel catalyst powder and heated to $380^{\circ} \mathrm{C}$. When the column effluent mixes with the FID hydrogen supply and passes through the methanizer, $\mathrm{CO}_{2}$ is converted to $\mathrm{CH}_{4}$. The carrier gas was helium at a flow rate of $30 \mathrm{cc} \cdot \mathrm{min}^{-1}$. The gas concentrations were expressed in $\mu$ mol $\times \mathrm{dm}^{-3}$ of gas in the water.

\section{Sediment analysis}

For porosity measurements, the water content per volume of sediment was determined by drying a known volume of the wet sediment to constant weight at $105^{\circ} \mathrm{C}$. The $\mathrm{pH}$ of the sediment in a suspension with $1 \mathrm{~N} \mathrm{KCl}$ was determined potentiometrically with a MultiLine P5 meter (WTW, Germany). The organic matter (OM) was in turn analyzed using the loss on ignition (LOI) method, at $550^{\circ} \mathrm{C}$ for $4 \mathrm{~h}$.

Prior to the analysis of organic carbon (TOC) and total nitrogen (TN), the samples were stripped of carbonate by means of $24 \mathrm{~h}$ contact with vapour from $30 \% \mathrm{HCl}$ in desiccators (Zimmermann et al. 1997). The OC and TN concentrations were subsequently measured using a $\mathrm{CN}$ analyzer $(\mathrm{CN}$ Flash EA 1112, ThermoQuest) at $1020^{\circ} \mathrm{C}$. Blank and standard samples of known elemental composition (sulphanilamide) were used in quality control, and the precision of the method overall was of about $\pm 3 \%$.

\section{CALCULATIONS}

Diffusive fluxes of pore-water gases from sediments were calculated by reference to Fick's first law of diffusion, whereby:

$$
J=-\phi D_{s}(d c / d z)
$$

where: $J$ is the diffusive flux,

$\phi$ is porosity,

$\mathrm{D}_{\mathrm{s}}$ the sediment diffusion coefficient for each individual gas, and

$\mathrm{dc} / \mathrm{dz}$ - the concentration change for each gas with depth.

$D_{s}$ was calculated after Berner (1980) and after Lerman (1979). The arithmetic mean of these two calculations was used for the diffusion values. After Berner:

$$
\mathrm{D}_{\mathrm{s}}=\mathrm{D}_{0} \theta^{-2}
$$

where: $D_{0}$ is the molecular diffusion coefficient in pure water, and $\theta^{2}$ the tortuosity of sediments (as estimated by reference to the empirical relationship developed by Sweerts (1990) for freshwater environments):

$$
\theta^{2}=-0.73 \phi+2.17
$$

After Lerman:

$$
\mathrm{D}_{\mathrm{s}}=\mathrm{D}_{0} \phi^{2}
$$

where: $D_{0}$ is the molecular diffusion coefficient in pure water, and $\phi$ is sediment porosity.

$D_{0}$ diffusion coefficients for $\mathrm{CH}_{4}$ in water were calculated using linear interpolation between values $0.95 \times 10^{-5} \mathrm{~cm}^{2} \times \mathrm{sec}^{-1}\left(5^{\circ} \mathrm{C}\right)$ and $1.5 \times 10^{-5}$ $\mathrm{cm}^{2} \times \mathrm{sec}^{-1}\left(20^{\circ} \mathrm{C}\right)$ (Lerman 1979). $\mathrm{D}_{0}$ values for $\mathrm{CO}_{2}$ in water were calculated after Hobler (1986). The concentration gradient was determined between the value in the water just above the sediment-water interface, and the first pore-water gas measurement (a ca. $1 \mathrm{~cm}$ depth interval).

\section{Statistical analysis}

For the obtained results, basic descriptive statistics such as the minimum, maximum, average and standard deviation values were calculated. For linear relationships, the $R^{2}$ values were determined as well. The MS Excel 2013 software was used for calculations.

\section{RESULTS AND DISCUSSION}

\section{Sediment characteristics}

The characteristic values for the selected parameters of the uppermost $1 \mathrm{~cm}$ of sediment are presented in Table 1.

The sediments collected are found to differ between both stations and Reservoirs. The sediments at the stations near the respective dams were sandy (at station M1) or sandy-clay (at station N1), and were characterized by lower porosity. Except at station M2, the sediments were slightly alkaline (in the $\mathrm{pH}$ range 7.20 to 7.99 ).

The contents of organic matter (OM) ranged from 0.16 to $19.32 \%$. The lowest value was noted for station M1, the highest at M2. Total organic carbon (TOC) accounted for about $30 \%$ of OM and ranged in content from 0.08 to $5.90 \%$. The observed trends were analogous to those noted 
Table 1. Selected parameters characterizing the uppermost $1 \mathrm{~cm}$ of the sediment layers in Maziarnia Reservoir (stations M1 and M2) and Nielisz Reservoir (stations N1 and N2); SD - standard deviation; n - number of measurements

\begin{tabular}{|c|c|c|c|c|c|c|c|c|c|c|c|c|}
\hline & \multicolumn{4}{|c|}{ Porosity $\left[\mathrm{cm}^{3} \times \mathrm{cm}^{-3}\right]$} & \multicolumn{4}{|c|}{$\mathrm{pH}$} & \multicolumn{4}{|c|}{ OM [\%] } \\
\hline & Min. & Max. & Average $\pm S D$ & $\mathrm{n}$ & Min. & Max. & & $\mathrm{n}$ & Min. & Max. & Average \pm SD & $\mathrm{n}$ \\
\hline M1 & 0.35 & 0.90 & $0.54 \pm 0.16$ & 8 & 7.36 & 7.80 & & 8 & 0.16 & 1.85 & $0.82 \pm 0.61$ & 8 \\
\hline M2 & 0.81 & 0.99 & $0.92 \pm 0.08$ & 8 & 5.08 & 6.80 & & 8 & 2.47 & 19.32 & $12.96 \pm 5.64$ & 8 \\
\hline N1 & 0.50 & 0.89 & $0.63 \pm 0.13$ & 8 & 7.40 & 7.99 & & 8 & 0.75 & 8.04 & $2.55 \pm 2.90$ & 8 \\
\hline \multirow[t]{3}{*}{$\mathrm{N} 2$} & 0.72 & 0.99 & $0.88 \pm 0.10$ & 8 & 7.20 & 7.51 & & 8 & 4.29 & 13.02 & $6.49 \pm 2.90$ & 8 \\
\hline & \multicolumn{4}{|c|}{ TOC [\%] } & \multicolumn{4}{|c|}{ TN [\%] } & \multicolumn{4}{|c|}{ C:N } \\
\hline & Min. & Max. & Average $\pm S D$ & $\mathrm{n}$ & Min. & Max. & Average $\pm S D$ & $\mathrm{n}$ & Min. & Max. & Average $\pm S D$ & $\mathrm{n}$ \\
\hline M1 & 0.08 & 0.87 & $0.22 \pm 0.27$ & 8 & 0.01 & 0.22 & $0.04 \pm 0.07$ & 8 & 3.95 & 13.88 & $9.35 \pm 3.01$ & 8 \\
\hline M2 & 0.98 & 5.90 & $4.06 \pm 1.93$ & 8 & 0.06 & 0.59 & $0.36 \pm 0.18$ & 8 & 9.92 & 16.33 & $11.82 \pm 2.01$ & 8 \\
\hline N1 & 0.21 & 2.54 & $0.82 \pm 0.80$ & 8 & 0.02 & 0.22 & $0.08 \pm 0.08$ & 8 & 4.26 & 33.33 & $13.30 \pm 8.61$ & 8 \\
\hline N2 & 1.03 & 4.77 & $2.56 \pm 1.14$ & 8 & 0.10 & 0.23 & $0.17 \pm 0.04$ & 8 & 10.00 & 14.79 & $14.79 \pm 3.35$ & 8 \\
\hline
\end{tabular}

for OM. Significant correlations between OM and TOC were obtained for both reservoirs, the values of $R^{2}$ were: $0.97(\mathrm{n}=16)$ and $0.86(\mathrm{n}=16)$ for Maziarnia and Nielisz, respectively.

The content of total nitrogen (TN) varied across the $0.01-0.59 \%$ range, and - as in the cases of OM and TOC - the highest contents were noted at station M2, the lowest at M1 and N1. The diversity of sediment chemical composition translated into varied values for the ratio of total organic carbon to total nitrogen $(\mathrm{C}: \mathrm{N})$. The $\mathrm{C}: \mathrm{N}$ values obtained were indicative of a mixed origin of organic matter deposited in the analyzed sediments.

\section{Pore-water characteristics}

The characteristic values for $\mathrm{CH}_{4}$ and $\mathrm{CO}_{2}$ concentrations in pore-water and in overlying water are presented in Table 2.

The concentrations of $\mathrm{CH}_{4}$ in the overlying water ranged from undetectable values to 136.36 $\mu$ mol $\times \mathrm{dm}^{-3}$ (Table 2). Higher concentrations of the gas at the stations located in upper parts of the Reservoirs (stations M2 and N2) were noted. The average concentrations at these stations were 24.38 and $34.26 \mu \mathrm{mol} \times \mathrm{dm}^{-3}$, respectively. The $\mathrm{CH}_{4}$ concentrations in the pore-water of the uppermost layer of sediment reached higher values in the range from undetectable values to 360 $\mu \mathrm{mol} \times \mathrm{dm}^{-3}$. As with overlying water, much higher concentrations were to be observed at stations M2 and N2.

The concentrations of $\mathrm{CO}_{2}$ were much higher than those of $\mathrm{CH}_{4}$. In overlying water, they ranged from 371 to $2891 \mu \mathrm{mol} \times \mathrm{dm}^{-3}$, in pore-water from 120.00 to $11480.00 \mu \mathrm{mol} \times \mathrm{dm}^{-3}$. Higher concentrations were noted at the stations M2 and N2, though the Reservoirs also differed significantly in this respect, with the measured concentrations in Nielisz Reservoir much higher than at Maziarnia (Table 2).

\section{Diffusive fluxes of $\mathrm{CH}_{4}$ and $\mathrm{CO}_{2}$ at the sediment-water interface}

The values for calculated diffusive fluxes of $\mathrm{CH}_{4}$ and $\mathrm{CO}_{2}$ at the sediment-overlying water interface are as shown in Figure 2.

The $\mathrm{CH}_{4}$ diffusion fluxes were low, in the ranges of $0-2.09 \mathrm{mmol} \times \mathrm{m}^{-2} \times \mathrm{d}^{-1}$ in the case of Maziarnia Reservoir, and -0.01-3.09 mmol $\times \mathrm{m}^{-}$ ${ }^{2} \times \mathrm{d}^{-1}$ in Nielisz Reservoir. Significant differences in fluxes between stations were observed for both Reservoirs, with markedly lower values obtained for the stations located near the respective dams, where the sediments are sandy. The average values for $\mathrm{CH}_{4}$ fluxes were 0.06 and $0.67{\mathrm{mmol} \times \mathrm{m}^{-}}^{-}$ ${ }^{2} \times \mathrm{d}^{-1}$ for stations $\mathrm{M} 1$ and $\mathrm{M} 2$, respectively, and 0.57 and $1.52 \mathrm{mmol} \times \mathrm{m}^{-2} \times \mathrm{d}^{-1}$ for stations $\mathrm{N} 1$ and $\mathrm{N} 2$, respectively.

The calculated values for the diffusive flux of $\mathrm{CO}_{2}$ at the sediment-water interface were higher, ranging from -1.00 to $9.43 \mathrm{mmol} \times \mathrm{m}^{-2} \times \mathrm{d}^{-1}$ and from -1.27 to $47.02 \mathrm{mmol} \times \mathrm{m}^{-2} \times \mathrm{d}^{-1}$ for Maziarnia and Nielisz Reservoirs, respectively. Significant differences between stations were observed for Maziarnia Reservoir. The average values for the fluxes of $\mathrm{CO}_{2}$ at stations $\mathrm{M} 1$ and M2 were -0.06 and $3.14 \mathrm{mmol} \times \mathrm{m}^{-2} \times \mathrm{d}^{-1}$, respectively. However, the differences between stations were much more limited at Nielisz than Maziarnia. The average values for $\mathrm{CO}_{2}$ fluxes were 8.42 and $6.84 \mathrm{mmol} \times \mathrm{m}^{-2} \times \mathrm{d}^{-1}$ for stations $\mathrm{N} 1$ and $\mathrm{N} 2$, respectively. The average value for fluxes at sta- 
Table 2. Concentrations of $\mathrm{CH}_{4}$ and $\mathrm{CO}_{2}$ in pore-water of the uppermost $1 \mathrm{~cm}$ of the sediment layer in Maziarnia Reservoir (stations M1 and M2), Nielisz Reservoir (N1 and N2); SD - standard deviation; $n$ - number of measurements

\begin{tabular}{|c|c|c|c|c|c|c|c|c|}
\hline \multirow{2}{*}{ Station } & \multicolumn{4}{|c|}{$\mathrm{CH}_{4}\left[\mu \mathrm{mol} \times \mathrm{dm}^{-3}\right]$} & \multicolumn{4}{|c|}{$\mathrm{CO}_{2}\left[\mu \mathrm{mol} \times \mathrm{dm}^{-3}\right]$} \\
\hline & M1 & M2 & N1 & N2 & M1 & M2 & N1 & N2 \\
\hline \multicolumn{9}{|c|}{ Overlying water } \\
\hline Minimum & n.d. & 0.82 & n.d. & 1.10 & 371 & 398 & 1276 & 1729 \\
\hline Maximum & 1.08 & 69.28 & 27.27 & 136.36 & 649 & 720 & 1735 & 2891 \\
\hline Average & 0.27 & 24.38 & 6.20 & 34.26 & 482 & 602 & 1499 & 2156 \\
\hline SD & 0.50 & 24.69 & 9.20 & 44.88 & 108 & 138 & 161 & 440 \\
\hline $\mathrm{n}$ & 8 & 8 & 8 & 8 & 8 & 8 & 8 & 8 \\
\hline \multicolumn{9}{|c|}{ Pore-water } \\
\hline Minimum & n.d. & 37.33 & n.d. & 30.66 & 120.00 & 493.33 & 1233.33 & 2133.33 \\
\hline Maximum & 205.33 & 320.00 & 360.00 & 346.66 & 960.00 & 1906.66 & 11480.00 & 3453.34 \\
\hline Average & 26.42 & 140.58 & 87.92 & 213.33 & 433.30 & 1072.07 & 3089.17 & 2827.79 \\
\hline SD & 72.31 & 94.58 & 159.90 & 107.03 & 267.33 & 515.09 & 3437.96 & 479.61 \\
\hline $\mathrm{n}$ & 8 & 8 & 8 & 8 & 8 & 8 & 8 & 8 \\
\hline
\end{tabular}

n.d. - not detected

tion N1 station was significantly underestimated owing to one incidentally high value obtained in August 2011 (of $47.02 \mathrm{mmol} \times \mathrm{m}^{-2} \times \mathrm{d}^{-1}$ ). When this value was excluded, the average $\mathrm{CO}_{2}$ flux at station $\mathrm{N} 1$ was $2.90 \mathrm{mmol} \times \mathrm{m}^{-2} \times \mathrm{d}^{-1}$.

No dependent relationship was to noted between the values obtained for the fluxes and either seasons of the year or water temperature, or parameters characterizing the Reservoir sediments. Significant relationships between the fluxes for $\mathrm{CH}_{4}$ and $\mathrm{CO}_{2}$ were obtained, however $\left(R^{2}=0.76\right.$; $\mathrm{n}=16$ for Maziarnia and $0.57 ; \mathrm{n}=15$ for Nielisz - following exclusion of the afore-mentioned outlier). This may all suggest that both gases are produced by the same process entailing fermentation.

The calculated fluxes for $\mathrm{CH}_{4}$ and $\mathrm{CO}_{2}$ at the sediment-overlying water interface were compared with values obtained by other researchers (Table 3), making it clear that for both $\mathrm{CH}_{4}$ and $\mathrm{CO}_{2}$ these are similar to findings for reservoirs experiencing eutrophication (falling within the range $0.2-19.27 \mathrm{mmol} \times \mathrm{m}^{-2} \times \mathrm{d}^{-1}$ and -0.06-17.70 mmol $\times \mathrm{m}^{-2} \times \mathrm{d}^{-1}$ for $\mathrm{CH}_{4}$ and $\mathrm{CO}_{2}$ fluxes, respectively) (Adams 2005). For better comparison, Table 3 presents the values for the diffusive fluxes of $\mathrm{CH}_{4}$ and $\mathrm{CO}_{2}$ obtained by other authors.

The comparison between the calculated diffusive fluxes of $\mathrm{CH}_{4}$ and $\mathrm{CO}_{2}$ at the sediment-overlying water interface and those measured at the water-air interface revealed that much higher values were reached in the latter case. For $\mathrm{CH}_{4}$, these ranged from 0 to 758.18 and from 0 to 426.50 mmol $\times \mathrm{m}^{-2} \times \mathrm{d}^{-1}$ for Maziarnia and Nielisz Reser- voirs, respectively. For $\mathrm{CO}_{2}$, they ranged from -4.70 to $138.78 \mathrm{mmol} \times \mathrm{m}^{-2} \times \mathrm{d}^{-1}$ and from 3.58 to $84.54 \mathrm{mmol} \times \mathrm{m}^{-2} \times \mathrm{d}^{-1}$ for Maziarnia Reservoir and Nielisz Reservoir, respectively (Gruca-Rokosz 2015; Gruca-Rokosz et al. 2017).

Such results indicate that the main pathway by which the $\mathrm{CH}_{4}$ from sediments in the Reservoirs studied is transported to the atmosphere is ebullition. In shallow-water ecosystems, methane bubbles formed in sediments can penetrate through the water column and be released into the atmosphere (Casper et al. 2000; Adams 2005; Huttunen et al. 2006). The amount of $\mathrm{CO}_{2}$ in gas bubbles is negligible (Jędrysek et al. 2014); hence, the much higher flux noted for this gas at the water-air interface confirms a high level of production in the water column. According to Abe et al. (2005), only $20 \%$ of $\mathrm{CO}_{2}$ emitted to the atmosphere comes from bottom sediments, while the rest comes from water.

\section{CONCLUSION}

The diffusion fluxes calculated for $\mathrm{CH}_{4}$ at the sediment-overlying water interface ranged from 0 to $2.09 \mathrm{mmol} \times \mathrm{m}^{-2} \times \mathrm{d}^{-1}$ in the case of Poland's Maziarnia Reservoir, and from -0.01 to $3.09 \mathrm{mmol} \times \mathrm{m}^{-2} \times \mathrm{d}^{-1}$ in the case of Nielisz Reservoir. In turn, the diffusive fluxes reported for $\mathrm{CO}_{2}$ range from -1.00 to $9.43 \mathrm{mmol} \times \mathrm{m}^{-2} \times \mathrm{d}^{-1}$ and from -1.27 to $47.02 \mathrm{mmol} \times \mathrm{m}^{-2} \times \mathrm{d}^{-1}$ for Maziarnia and Nielisz Reservoirs, respectively. Such fluxes are characteristic for eutrophicated reservoirs. No de- 

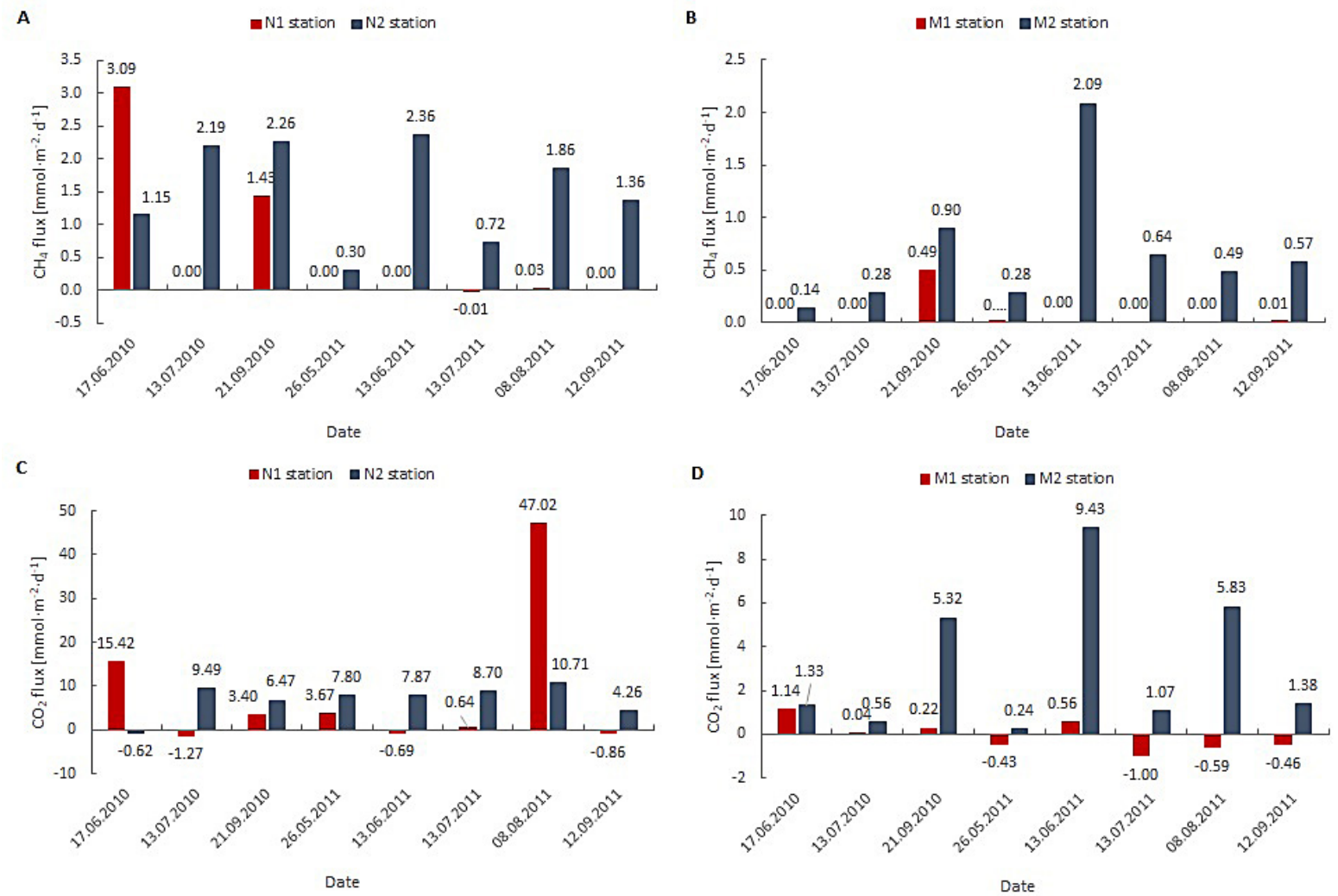

Fig. 2. Diffusive fluxes of $\mathrm{CH}_{4}$ (panels $\mathrm{A}$ and $\mathrm{B}$ ) and $\mathrm{CO}_{2}$ (panels $\mathrm{C}$ and $\mathrm{D}$ ) at the sediment-water interfaces in the reservoirs studied

Table 3. Diffusive fluxes of $\mathrm{CH}_{4}$ and $\mathrm{CO}_{2}$ at the sediment-overlying water interface in different aquatic environments (ranges or averages)

\begin{tabular}{|c|c|c|c|}
\hline Reservoir & $\begin{array}{c}\mathrm{CH}_{4} \text { flux } \\
\left(\mathrm{mmol} \times \mathrm{m}^{-2 \times} \mathrm{d}^{-1}\right)\end{array}$ & $\begin{array}{c}\mathrm{CO}_{2} \text { flux } \\
\left(\mathrm{mmol} \times \mathrm{m}^{-2 \times} \mathrm{d}^{-1}\right)\end{array}$ & References \\
\hline Maziarnia Reservoir (Poland) & $0.00-2.09$ & $-1.00-9.43$ & This study \\
\hline Nielisz (Poland) & $-0.01-3.09$ & $-1.27-47.02$ & This study \\
\hline Rzeszów Reservoir (Poland) & $0.01-2.19$ & $0.36-45.33$ & Gruca-Rokosz and Tomaszek 2015 \\
\hline Solina Reservoir (Poland) & & $1.08-1.51$ & Gruca-Rokosz et al. 2011 \\
\hline Tuusulanjärvi Lake (Finland) & 4.50 & & Huttunen et al. 2006 \\
\hline Postilampi Lake (Finland) & 6.56 & & Huttunen et al. 2006 \\
\hline Soiviojärvi Lake (Finland) & 0.54 & & Huttunen et al. 2006 \\
\hline Takajärvi Lake (Finland) & 0.30 & & Huttunen et al. 2006 \\
\hline Luminakajärvi Lake (Finland) & 1.69 & & Huttunen et al. 2006 \\
\hline Ranuajärvi Lake (Finland) & 4.75 & & Huttunen et al. 2006 \\
\hline Lokka Reservoir (Finland) & 0.03 & & Huttunen et al. 2006 \\
\hline Porttipahta Reservoir (Finland) & 1.56 & & Huttunen et al. 2006 \\
\hline Lobo Broa Reservoir (Brazil) & $5.34-15.00$ & $8.80-26.05$ & Adams 2005 \\
\hline Stechlin Lake (Germany) & $0.05-0.20$ & $2.30-3.40$ & Casper et al. 2003 \\
\hline Bled Lake (Slovenia) & 2.20 & 5.10 & Ogrinc et al. 2002 \\
\hline Orta Lake (Italy) & $0.13-7.37$ & & Adams and Baudo 2001 \\
\hline Eutrophic Reservoir & $0.2-19.27$ & $-0.06-17.70$ & Adams 2005 \\
\hline
\end{tabular}


pendent relationships could be found between the values for the calculated diffusion fluxes and either seasons or water temperature, or parameters characterizing the sediments analyzed.

\section{Acknowledgments}

The study was supported by Poland's Ministry of Science, via grant no. N N305 077836.

\section{REFERENCES}

1. Abe D.S., Adams D.D., Sidagis Galli C.V., Sikar E., Tundisi J.G. 2005. Sediment greenhouse gases (methane and carbon dioxide) in the Lobo-Broa Reservoir, São Paulo state, Brazil: concentrations and diffuse emission fluxes for carbon budget considerations. Lakes \& Reservoirs: Research and Management, 10, 201-209.

2. Adams D.D. 2005. Diffuse flux of greenhouse gases - methane and carbon dioxide - at the sediment-water interface of some lakes and reservoirs of the world. In: Tremblay A., Varfalvy L., Roehm C., Garneau M. (Eds.) Greenhouse gas emissions fluxes and processes. Hydroelectric reservoirs and natural environments.

3. Adams D.D., Baudo R. 2001. Gases $\left(\mathrm{CH}_{4}, \mathrm{CO}_{2}\right.$ and $\mathrm{N}_{2}$ ) and pore water chemistry in the surface sediments of Lake Orta, Italy: acidification effects on $\mathrm{C}$ and $\mathrm{N}$ gas cycling. J. Limnol., 60(1), 79-90.

4. Bartoszek L., Koszelnik, P. 2016. The qualitative and quantitative analysis of the coupled C, N, P and Si retention in complex of water reservoirs. SpringerPlus, 5, 1157.

5. Bartoszek L., Tomaszek J.A. 2011. Analysis of the spatial distribution of phosphorus fractions in the bottom sediments of the Solina-Myczkowce dam reservoir complex. Environment Protection Engineering, 37(3), 5-15.

6. Bartoszek L., Tomaszek J.A. 2016. The influence of selected variables on the phosphorus content in bottom sediments of the Solina-Myczkowce complex of dam reservoirs. Fresenius Environmental Bulletin, 25(10), 3859-3866.

7. Berner R.A. 1980. Early diagenesis: a theoretical approach. Princeton University Press, Princeton, N.Y.

8. Casper P., Maberly S.C., Hall G.H., Finlay B.J. 2000. Fluxes of methane and carbon dioxide from a small productive lake to the atmosphere. Biogeochemistry, 49, 1-19.

9. Casper P., Furtado A., Adams D.D. 2003. Biogeochemistry and diffuse fluxes of greenhouse gases (methane and carbon dioxide) and dinitrogen from the sediments in oligotrophic Lake Stechlin. In: Lake Stechlin: an approach to understand an oligotrophic lowland lake. Eds: Koschel R., Adams D.D. Arch Hydrobiol Spec Iss Adv Limnol, 58, 53-71.

10. Gruca-Rokosz R. 2015. Dynamics of carbon greenhouse gases in reservoirs: production pathways, emissions to atmosphere (in Polish). Oficyna Wydawnicza Politechniki Rzeszowskiej, 1-132.

11. Gruca-Rokosz R., Bartoszek L., Koszelnik P. 2017. The influence of environmental factors on the carbon dioxide flux across the water-air interface of reservoirs in south-eastern Poland. Journal of Environmental Sciences, 56, 290-299.

12. Gruca-Rokosz R., Tomaszek J.A. 2015. Methane and carbon dioxide in the sediment of a eutrophic reservoir: production pathways and diffusion fluxes at the sediment-water interface. Water, Air and Soil Pollution, 226, 16, DOI: 10.1007/ s11270-014-2268-3.

13. Gruca-Rokosz R., Tomaszek J.A., Koszelnik P., Czerwieniec E. 2011a. Methane and carbon dioxide fluxes at the sediment-water interface in reservoir. Polish J. of Environ. Stud., 20(1), 81- 86.

14. Hobler T. 1986. Heat movement and exchangers (in Polish). Wydawnictwo Naukowo-Techniczne Warszawa.

15. IPCC Climate Change, Synthesis report, 2007.

16. Jędrysek M.O., Hałas S., Pieńkos T. 2014. Carbon isotopic composition of early-diagenetic methane: variations with sediments depth. Annales Universitatis Mariae Curie-Skłodowska, LXIX, 29-52.

17. Lerman A. 1979. Geochemical processes water and sediment environment. John Wiley and Sons, NY.

18. Miyajima T., Yamada Y., Hanba Y.T. 1995. Determining the stable isotope ratio of total dissolved inorganic carbon in lake water by GC/C/IRMS. Limnol. Oceanogr., 40(5), 994-1000.

19. Ogrinc N., Lojen S., Faganeli J. (2002). A mass balance of carbon stable isotopes in an organicrich methane-producing lacustrine sediment (Lake Bled, Slovenia). Global and Planetary Change, 33, 57-72.

20. Reeburgh W.S. 1980. Anaerobic methane oxidation: Rate depth distributions in Skan Bay sediments. Earth Planet. Sci. Lett., 47, 345-352.

21. Sweerts J.-P.R.A. 1990. Oxygen consumption processes, mineralization and nitrogen cycling at the sediment - water interface of north temperate lakes. Ph.D. Thesis, Rijksuniversitet, Groningen.

22. Zimmermann C.F., Keefe C.W., Bashe J. 1997. Determination of carbon and nitrogen in sediments and particulates/coastal waters using elemental analysis. Method 440.0. NER laboratory, U.S. EPA, Cincinnati, Ohio. 